\title{
Angiopoietin-related growth factor level in preeclampsia
}

\section{Preeklampside Angiopoietin-ilişkili büyüme faktör seviyesi}

\section{Abdullah Boztosun*, Köksal Deveci, Remzi Atılgan, Melike Sinem Söylemez, Ali Yanık, İptisam İpek Müderris}

Departments of Obstetrics and Gynecology (Asist. Prof. A. Boztosun, MD, Prof. Ali Yanık, MD) and Biochemistry (Asist. Prof. K. Deveci, MD), Cumhuriyet University, School of Medicine, TR58140 Sivas, Department of Obstetrics and Gynecology (Asist. Prof. R. Atılgan, MD), Firat University, School of Medicine, TR-23119 Elazığg, Department of Obstetrics and Gynecology (M. S. Söylemez, MD, Prof. İ. İ. Müderris, MD), Erciyes University, School of Medicine, TR-38039 Kayseri

\begin{abstract}
Aim. Angiopoietin-related growth factor (AGF) is associated with angiogenesis but it can also affect glucose and energy metabolism. The aim of this study was to determine AGF levels in preeclampsia. Method. The study included 32 women with preeclampsia (preeclampsia group) and 32 non-preeclamptic, healthy, third trimester pregnant women (Control group). We analyzed serum levels of AGF and other biochemical and anthropometric markers in all subjects. Results. Serum AGF levels were significantly higher in subjects with preeclampsia $(98.6 \mathrm{ng} / \mathrm{mL})$ than those in the control group $(52.2 \mathrm{ng} / \mathrm{mL})$, (p-value<0.001). In preeclampsia group, mean sistolic blood pressure and mean diastolic blood pressure were found significantly higher than in control group (157.5 mm Hg/114.6 mm Hg, $100.9 \mathrm{~mm} \mathrm{Hg/70.0} \mathrm{mm} \mathrm{Hg} \mathrm{respectively).} \mathrm{Also} \mathrm{mean} \mathrm{arterial}$ pressure in preeclampsia group was significantly higher than in control group $(119.7 \mathrm{~mm} \mathrm{Hg} / 84.8$ $\mathrm{mm} \mathrm{Hg}$ ) (p-value<0.001). There was a significant positive association between AGF and systolic blood pressure, mean arterial pressure in preeclampsia group but there was no relationship between AGF and homeostasis model of assessment insulin resistance (HOMA-IR). Conclusion. Although systolic blood pressure can be a predictor of serum AGF level in preeclampsia, further studies are needed to explain the physiologic roles of AGF in physiopathology of preeclampsia.
\end{abstract}

Keywords: Angiopoietin-related growth factor, preeclampsia

\section{Özet}

Amaç. Angiopoietin-ilişkili büyüme faktörü anjiogenez ile ilişkilidir fakat glukoz ve enerji metabolizmasınıda etkileyebilmektedir. Bu çalışmanın amacı preeklampside Angiopoietin-ilişkili büyüme faktörünün serum seviyelerinin belirlenmesidir. Yöntem. Çalışma 32 preeklampsili kadın (preeklampsi grubu) ve 32 sağlıklı 3. trimesterde gebe kadın (Kontrol grubu) ile yapıldı. Tüm olgularda, Angiopoietin-ilişkili büyüme faktörünün serum seviyeleri ile birlikte diğer biyokimyasal ve antropometrik veriler analiz edildi. Bulgular. Preeklampsili olgularda Angiopoietin-ilişkili büyüme faktörünün serum seviyeleri $(98,6 \mathrm{ng} / \mathrm{mL})$ kontrol grubundan $(52,2$ $\mathrm{ng} / \mathrm{mL}$ ) anlamlı yüksekti (p-değeri<0,001). Preeklampsi grubunun ortalama sistolik kan basınc1 ve ortalama diastolic kan basıncı değerleri kontrol grubundan anlamlı yüksek bulundu (sırasıyla 157,5 $\mathrm{mm} \mathrm{Hg} / 114,6 \mathrm{~mm} \mathrm{Hg}, 100,9 \mathrm{~mm} \mathrm{Hg} / 70,0 \mathrm{~mm} \mathrm{Hg}$ ). Ayrıca, ortalama arteryel basınç da preeklampsi grubunda kontrol grubundan anlamlı yüksekti $(119,7 \mathrm{~mm} \mathrm{Hg} / 84,8 \mathrm{~mm} \mathrm{Hg}$ (pdeğeri<0,001). Preeklampsi grubunda, Angiopoietin-ilişkili büyüme faktörün’ün serum seviyeleri ile sistolik kan basıncı ve ortalama arteryel basınç arasında pozitif ilişki tespit edildi ancak insülin direnci indeksi(HOMA-IR) ile ilişki tespit edilmedi. Sonuç. Sistolik kan basınc1, preeklampsili hastalarda serum Angiopoietin-ilişkili büyüme faktörün'ün seviyeleri için bir belirleyici olabilir ancak preeklampsinin fizyopatolojisinde Angiopoietin-ilişkili büyüme faktörün'ün fizyolojik rolünün açıklanması için başka çalışmalarada ihtiyaç vardır.

Anahtar sözcükler: Angiopoietin-ilişkili büyüme faktörü, preeklampsi 


\section{*Corresponding author:}

Dr. Abdullah Boztosun, Kadın Doğum Anabilim Dalı, Cumhuriyet Üniversitesi Tıp Fakültesi, TR58140 Sivas. E-posta: abdullahboztosunyrd@hotmail.com

\section{Introduction}

Preeclampsia is a pregnancy-related disorder defined as the new onset of hypertension and proteinuria in the second half of pregnancy [1]. The adverse acute and chronic clinical impact on the mother and the child is severe and the cost to society is immense [2]. The pathogenesis of the disease is far from understood; however, the last decade has brought a plethora of new and interesting information, particularly regarding the role of the angiogenic balance in the disease. Preeclampsia features a shift in angiogenesis and anti-angiogenic factors towards a maladaptive placental circulation [3]. Angiopoietin-like proteins (ANGPTLs) are structurally similar to angiopoietins. To date, seven angiopoietin-like proteins (ANGPTL 1-7) were identified [4, 5]. Angiopoietin-related growth factor (AGF) is as a member of ANGPTL family and known as ANGPTL-6. AGF is mainly synthesized in the liver, and then passes through the circulation [6]. The overall effect of AGF is associated with angiogenesis and act as pro-angiogenic factors [5]. Some of the angiopoietin-like proteins, including AGF, can affect glucose, lipid and energy metabolism. These effects are independent of their effects on angiogenesis [7]. The aim of this study was to investigate whether AGF is affected in patients with preeclampsia.

\section{Material and method}

The study was approved by the local Ethical Committee and written informed consent was obtained from all the pregnant women of ages between 20 and 39 years. Thirty four women diagnosed as preeclampsia (preeclampsia group) and 33 non-preeclamptic, healthy, third trimester pregnant women were (control group) included in this study. After determination of serum AGF levels, 2 subjects in preeclampsia group and 1 subject in control group, who showed extremely high or low levels of serum AGF, were excluded. Preeclampsia was diagnosed according to the Report of the National High Blood Pressure Education Program Working Group on High Blood Pressure in Pregnancy [8] and significant proteinuria was defined as total protein $\geq 300 \mathrm{mg}$ in a 24 -h urine collection or $\geq 1+$ proteinuria by dipstick in a random urine analysis with no evidence of urinary tract infection. A standardized questionnaire was used to collect details pertaining to their anthropometrics, family history, medical and obstetric history, and other relevant information. Each subject underwent a complete medical examination as well as a hematological, hepatic and renal function analysis. None of the patients described personal history of hypertension, thrombo-embolic disease, endocrine diseases or cardiovascular events. Body mass index (BMI) was calculated at the time of pregnancy and before pregnancy in all subjects. Systolic blood pressure (SBP) and diastolic blood pressure (DBP) were recorded. Mean arterial pressure (MAP) was calculated as following: $(\mathrm{MAP}=\mathrm{DBP}+(\mathrm{SBP}-\mathrm{DBP}) / 3)$.

\section{Study protocol}

In the preeclamptic patients, blood sample was drawn within three days following the diagnosis of preeclampsia. At the time of the blood sampling, none of the women was in labor and magnesium sulfate treatment. In preeclampsia and control groups, peripheral venous blood were taken after fasting for at least eight hours to measure serum insulin, plasma glucose, AGF levels and liver-kidney functions. Sera obtained from all subjects was immediately separated by centrifugation at $4,000 \mathrm{~g}$ for $10 \mathrm{~min}$ and frozen at $-80{ }^{\circ} \mathrm{C}$. Serum insulin level was assayed by enzyme-linked immunoassay (ADVIA Centaur, Bayer, and Tarrytown, NY, USA). The intra-assay and total coefficients of variation were 6.1 and $7.1 \%$ respectively. Insulin resistance score was determined by using homeostasis 
model assessment (HOMA-IR $=$ fasting insulin $(\mathrm{mU} / \mathrm{L}) \times$ fasting glucose $(\mathrm{mg} / \mathrm{dL}) \times 0.05551 / 22.5)[9]$.

Glucose was measured by using the hexokinase method at Synchron LX20 systems (Beckman Coulter, Fullerton, Calif.USA) with an intra-measurement coefficient of variance of $0.92-1.54 \%$. Serum levels of AST (aspartate transaminase), ALT (alanine transaminase), BUN (blood urea nitrogen) and creatinine were measured at Synchron LX20 systems (Beckman Coulter, Fullerton, Calif.USA) with the original Beckman Synchron LX system reagents. The serum ANGPTL6 levels were measured by enzymelinked immunosorbent assay (Uscn Kit, Life Science Inc., Wuhan, P.R. China). The intraassay coefficient of variation was $5.4 \%$ at $15.6 \mathrm{ng} / \mathrm{mL}, 4.8 \%$ at $62.5 \mathrm{ng} / \mathrm{mL}$, and $3.1 \%$ at $125.0 \mathrm{ng} / \mathrm{mL}$. The minimum detectable dose of ANGPTL6 was typically less than $5.8 \mathrm{ng} / \mathrm{mL}$.

\section{Statistical Analyses}

All data were analyzed by using SPSS software version 15.0 (Chicago, IL, USA). All variables are reported as mean (25th percentile, 75th percentile). Differences between groups were evaluated by using Mann-Whitney U test. Spearman correlation was also used. Non-normally distributed variables were log-transformed for Analysis of covariance (ANCOVA). We considered $\mathrm{p}$ value $<0.05$ as statistically significant.

\section{Results}

General baseline characteristics of patients in preeclampsia and the control group have been summarized in Table 1. There was no difference between groups with respect to age, parity, gestational age, weight ) in pregnancy and before pregnancy. There was also no difference between groups in HOMA-IR, fasting insulin, fasting glucose and aspartate transaminase levels. Mean pre-gestational BMI and gestational BMI were higher in the preeclampsia group compared to control group but not significant $(p>0.05)$. SBP and DBP, and MAP significantly higher in preeclampsia group than in control group $(p<0.001)$. Alanine transaminase were also significantly higher in preeclampsia group than in control group $(\mathrm{p}<0.05)$. In addition to these results, mean AGF level was significantly higher in preeclampsia group than in control group $(\mathrm{p}<0.001)$, (Table 1$)$.

Table 1.Characteristics of study population.

\begin{tabular}{llll}
\hline & $\begin{array}{l}\text { Control group } \\
(\mathbf{n = 3 2})\end{array}$ & $\begin{array}{l}\text { Preeclampsia group } \\
(\mathbf{n = 3 2})\end{array}$ & p-value \\
\hline Age (year) & $27.9(24.2,31.7)$ & $28.7(25.2,32.0)$ & .553 \\
Gravidity & $2.3(1.0,3.0)$ & $2.5(2.0,3.0)$ & .501 \\
Parity & $1.0(0.0,2.0)$ & $1.3(0.2,2.0)$ & .302 \\
Gestational age (. week) & $33.7(31.2,36.0)$ & $34.9(33.0,37.0)$ & .086 \\
Pregestational weight $(\mathrm{kg})$ & $63.9(58.0,70.0)$ & $64.5(58.0,70.0)$ & .876 \\
Gestational weight $(\mathrm{kg})$ & $72.566 .0,80.0$ & $73.766 .2,80.0$ & .647 \\
Pregestational BMI $\left(\mathrm{kg} / \mathrm{m}^{2}\right)$ & $24.222 .0,25.9$ & $24.522 .1,26.0$ & .804 \\
Gestational BMI $\left(\mathrm{kg} / \mathrm{m}^{2}\right)$ & $27.4(24.6,29.7)$ & $28.0(24.6,30.5)$ & .596 \\
Sistolic blood pressure $(\mathrm{mm} \mathrm{Hg})$ & $114.6(110.0,125.0)$ & $157.5(145.0,160.0)$ & $.000^{*}$ \\
Diastolic blood pressure (mm Hg) & $70.0(65.0,75.0)$ & $100.9(95.0,107.5)$ & $.000^{*}$ \\
Mean arterial pressure (mm Hg). & $84.8(77.0,91.6)$ & $119.7(115.0,121.2)$ & $.000^{*}$ \\
Fasting glucose(mmol/l) & $82.7(75.2,88.7)$ & $86.0(76.0,96.2)$ & .528 \\
Fasting insulin(U/mL) & $8.7(6.5,10.8)$ & $7.7(2.9,11.7)$ & .155 \\
HOMA-IR & $1.7(1.2,2.4)$ & $1.6(0.5,2.6)$ & .289 \\
AGF(ng/mL) & $52.2(30.0,61.0)$ & $98.6(45.5,138.9)$ & $.000^{*}$ \\
BUN (mg/dL) & $13.9(8.0,18.0)$ & $18.8(9.0,23.0)$ & .136 \\
Creatinine (mg/dL) & $0.7(0.5,0.9)$ & $0.8(0.6,1.1)$ & .084 \\
AST (IU/mL) & $21.0(16.0,27.7)$ & $32.4(17.0,35.5)$ & .056 \\
ALT (IU/mL) & $20.1(13.0,24.7)$ & $31.2(18.0,34.7)$ & $.033^{*}$ \\
\hline
\end{tabular}

* statisticaly significant, GDM: Gestational diabetes mellitus, BMI: Body mass index, HOMA-

IR: Homeostasis Model of Assessment - Insulin Resistance, AGF: Angiopoietin-related Growth Factor, BUN: Blood urea nitrogen. AST: Aspartate transaminase, ALT: Alanine transaminase 
Simple correlations between serum AGF levels and biochemical and anthropometric markers were analyzed by Spearman correlation test within the control and preeclampsia groups. Systolic blood pressure and mean arterial pressure showed significantly positive correlation with AGF in preeclampsia group (Table 2). The most powerful and statistically significant relationship was detected between AGF and systolic blood pressure. When the effect of systolic blood pressure on groups was removed by ANCOVA, it was seen that the difference between two groups was insignificant $(\mathrm{F}=0.396, \mathrm{p}=0.531)$.

Table 2. Correlation between serum AGF levels and biochemical and anthropometric markers.

\begin{tabular}{lllll}
\hline & \multicolumn{2}{l}{ Control group $(\mathbf{n}=32)$} & \multicolumn{2}{l}{ Preeclampsia group (n=32) } \\
& r-value & p-value & r-value & p-value \\
\hline Age (year) & .259 & .153 & -.150 & .413 \\
Gravidity & .245 & .177 & -.186 & .309 \\
Parity & .137 & .455 & -.246 & .174 \\
Gestational age (week) & .296 & .100 & -.283 & .116 \\
Pregestational weight (kg) & -.079 & .666 & -.051 & .782 \\
Gestational weight(kg) & -.034 & .853 & -.110 & .550 \\
Pregestational BMI & -.275 & .128 & -.202 & .266 \\
Gestational BMI & -.174 & .339 & -.155 & .398 \\
SBP (mmHg) & .240 & .185 & $.439 *$ & $.012^{*}$ \\
DBP (mmHg) & .152 & .406 & .291 & .107 \\
MAP (mmHg) & .254 & .161 & $.353 *$ & $.048^{*}$ \\
AST (IU/mL) & -.035 & .848 & -.094 & .608 \\
ALT (IU/mL) & -.141 & .440 & -.151 & .410 \\
BUN (mg/mL) & -.140 & .446 & -.084 & .648 \\
Creatinine(mg/dL) & .089 & .630 & .030 & .871 \\
Fasting glucose(mmol/l) & .015 & .934 & -.264 & .145 \\
Fasting insulin(U/mL) & -.062 & .735 & -.074 & .689 \\
HOMA-IR & .032 & .864 & -.147 & .423 \\
\hline * statisticaly significant, GDM: Gestational diabetes mellitus, AGF: Angiopoietin-related Growth \\
Factor, BMI: Body mass index, BUN: blood urea nitrogen, HOMA-IR: Homeostasis Model of \\
Assessment - Insulin Resistance, SBP: Sistolic blood pressure, DBP: Diastolic blood pressure, \\
MAP: Mean arterial pressure, AST: Aspartate transaminase, ALT: Alanine transaminase \\
\hline
\end{tabular}

\section{Discussion}

To our knowledge, this is the second study comparing AGF levels between patients with preeclampsia and healthy pregnant controls. In the current study, we demonstrated that serum AGF levels were significantly higher in patients with preeclampsia. Furthermore, statistically significant positive correlation was found between AGF and systolic blood pressure or mean arterial pressure in patients with preeclampsia. The overall effect of AGF is associated with angiogenesis and act as pro-angiogenic factors [10]; in addition, AGF can promote epidermal proliferation, remodeling and regeneration [11]. AGF can also affect glucose, lipid and energy metabolism. These effects are independent of its effects on angiogenesis [7]. On the other hand, currently, there is limited numbers of study, investigating AGF in humans. In the single study, in which relationship between pre-eclampsia and AGF was evaluated, authors proposed that serum levels of AGF would be lower in preeclamptic patients than healthy controls [12]. The reason of this assumption is the fact that pro-angiogenic growth factors including placental growth factor were shown to be decreased in patients with preeclampsia [13]. However, on the contrary to expectation, serum AGF level was found to be higher in pregnant women with preeclampsia [12]. In an animal study, it was demonstrated that increasing amounts of AGF were related to increased energy consumption; caused insulin sensitivity; and had favorable effect on lipid profile in AGF-transgenic mice, whereas obese mice treated to AGF showed improved glucose tolerance and increased insulin sensitivity [6]. However, 
it was failed to show these favorable effects of AGF on lipid metabolism and glucose metabolism in human studies. Namkung et al. [14] reported that AGF levels were higher in patients with metabolic syndrome compared to those in control group. In that study, it was found that HOMA-IR index and BMI showed paradoxical correlation between the groups; as being positive in the healthy group and negative in the metabolic syndrome group. The authors of the study suggest that this paradox shows a possibility of AGF resistance [14]. We conducted a trial with hypothesis of AGF would be lower in patients with polycystic over syndrome (PCOS). However, we also found that AGF was increased in patient with PCOS inconsistent to our initial hypothesis (data not published). Stepan et al. [12] reported that maternal AGF serum levels are significantly and paradoxically higher in preeclampsia during pregnancy, and median postpartum circulating AGF levels are similar in preeclampsia and normal pregnancies. Furthermore, they were demonstrated that preeclampsia and SBP were associated with AGF levels in multivariate analyses independent of maternal age [12]. In the current study, systolic blood pressure and mean arterial pressure were shown to have significantly positive correlation with higher AGF level in preeclampsia group. Stepan et al. [12] proposed that AGF levels in pre-eclampsia might be increased for compensation of impaired angiogenesis and the effects of nitric oxide in preeclampsia.Namkung et al. [14] reported that age showed a negative association with AGF level; also serum creatinine levels were negatively correlated to AGF level, whereas body mass index positively. In our study, no significant relationship was shown between AGF and these variables. We believe that it can be resulted from distinct study population in our study.

In conclusion, the association between AGF and metabolism or angiogenesis, which was established in animal studies, isn't consistent to limited human studies. AGF levels are increased in patients with preeclampsia. Comprehensive studies, investigating relationship between preeclampsia and AGF, may shed light on physiopathology of preeclampsia.

\section{References}

1. Brown MA, Lindheimer MD, de Swiet M, Van Assche A, Moutquin JM. The classification and diagnosis of the hypertensive disorders of pregnancy: statement from the International Society for the Study of Hypertension in Pregnancy (ISSHP). Hypertens Pregnancy 2001; 20: IX-XIV.

2. Sibai B, Dekker G, Kupferminc M. Pre-eclampsia. Lancet 2005; 365: 785-99.

3. Verlohren S, Stepan H, Dechend R. Angiogenic growth factors in the diagnosis and prediction of pre-eclampsia. Clin Sci (Lond) 2012; 122: 43-52.

4. Oike Y, Tabata M. Angiopoietin-like proteins--potential therapeutic targets for metabolic syndrome and cardiovascular disease. Circ J 2009; 73: 2192-7.

5. Oike Y, Yasunaga K, Suda T. Angiopoietin-related/angiopoietin-like proteins regulate angiogenesis. Int J Hematol 2004; 80: 21-8.

6. Oike Y, Akao M, Yasunaga K, Yamauchi T, Morisada T, Ito Y, Urano T, Kimura Y, Kubota Y, Maekawa H, Miyamoto T, Miyata K, Matsumoto S, Sakai J, Nakagata N, Takeya M, Koseki H, Ogawa Y, Kadowaki T, Suda T. Angiopoietin-related growth factor antagonizes obesity and insulin resistance. Nat Med 2005; 11: 400-8.

7. Kadomatsu T, Tabata M, Oike Y. Angiopoietin-like proteins: emerging targets for treatment of obesity and related metabolic diseases. FEBS J 2011; 278: 55964.

8. Report of the National High Blood Pressure Education Program Working Group on High Blood Pressure in Pregnancy. Am J Obstet Gynecol 2000; 183: S1-S22.

9. Radikova Z, Koska J, Huckova M, Ksinantova L, Imrich R, Vigas M, Trnovec T, Langer P, Sebokova E, Klimes I. Insulin sensitivity indices: a proposal of cut-off points for simple identification of insulin-resistant subjects. Exp Clin Endocrinol Diabetes 2006; 114: 249-56. 
10. Oike Y, Ito Y, Maekawa H, Morisada T, Kubota Y, Akao M, Urano T, Yasunaga $\mathrm{K}$, Suda T. Angiopoietin-related growth factor (AGF) promotes angiogenesis. Blood 2004; 103: 3760-5.

11. Oike Y, Yasunaga K, Ito Y, Matsumoto S, Maekawa H, Morisada T, Arai F, Nakagata N, Takeya M, Masuho Y, Suda T. Angiopoietin-related growth factor (AGF) promotes epidermal proliferation, remodeling, and regeneration. Proc Natl Acad Sci USA 2003; 100: 9494-9.

12. Stepan H, Ebert T, Schrey S, Reisenbüchler C, Stein S, Lossner U, Bluher M, Stumvoll M, Kratzsch J, Faber R, Fasshauer M. Serum levels of angiopoietinrelated growth factor are increased in preeclampsia. Am J Hypertens 2009; 22: 314-8.

13. Stepan H, Unversucht A, Wessel N, Faber R. Predictive value of maternal angiogenic factors in second trimester pregnancies with abnormal uterine perfusion. Hypertension 2007; 49: 818-24.

14. Namkung J, Koh SB, Kong ID, Choi JW, Yeh BI. Serum levels of angiopoietinrelated growth factor are increased in metabolic syndrome. Metabolism 2011; 60: 564-8. 